IJBPAS, November, 2020, 9(11): 3211-3217

ISSN: 2277-4998

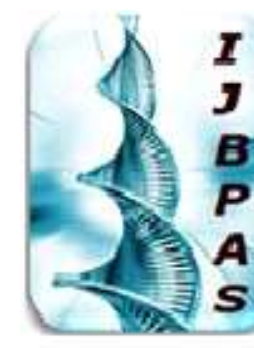

\author{
International Journal of Biology, Pharmacy \\ and Allied Seiences (IJBPAS) \\ 'A B ridge Betusen Caboratory and Q Qndor'
}

WWW.iibpas.com

\title{
GLOMERELLA CINGULATA SPORE GERMINATION AND CHITINASE DETECTION IN RESISTANCE-INDUCED TEA PLANTS
}

SOM PAUL $\mathbf{R}^{*}$

Department of Botany, Siliguri College, Siliguri -734001, West Bengal, India

*Corresponding Author: Rita Som Paul: E Mail: somrita25@gmail.com

Received 17 $7^{\text {th }}$ March 2020; Revised 20 ${ }^{\text {th }}$ April 2020; Accepted $12^{\text {th }}$ May 2020; Available online $1^{\text {st }}$ Nov. 2020

\section{https://doi.org/10.31032/IJBPAS/2020/9.11.5235}

ABSTRACT

Elucidation of the mechanism behind induced resistance of tea plants with Benzothiadiazole (BTH) was done in the present study. The progress of Glomerella cingulata (Stoneman) Spauld \& Schrenk (brown blight pathogen) spore germination, appressoria formation and germ tube length were calculated at $24 \mathrm{~h}$. SDS-PAGE analysis showed an extra $12 \mathrm{kDa}$ protein in treated plants. Western Blot with polyclonal antibody of chitinase showed a distinct band of $29 \mathrm{kDa}$ in the treated inoculated plants.

Keywords: induced resistance, tea, spore germination, Glomerella cingulata, chitinase

\section{INTRODUCTION}

Induced resistance in plants is a very important phenomenon that needs to be studied in details to ascertain its mechanism of action. Now-a-days there is a thrust on novel inducers which do not have any residual effects in crops. Tea is an important plantation crop of North-East India, which needs special attention as its tender leaves act as host to numerous phytopathogens [1]. Brown blight of tea is caused by Glomerella cingulata (Stoneman) Spauld \& Schrenk [2].
Benzothiadiazole (BTH), a well-known systemic resistance inducer, was earlier successfully used to protect tea plants from brown blight infection [3]. Mechanism of action of this inducer was further elucidated in the present paper by observing spore germination of the pathogen, Glomerella cingulata, and by SDS-PAGE and Western Blot with PAb (Polyclonal Antibody) of chitinase. 


\section{MATERIALS AND METHODS}

Plant material: Eighteen months old tea [Camellia sinensis (L.)O. Kuntze] saplings were obtained from cuttings made from shoots of the mother bush of the TV-22 tea variety maintained in Tea Germplasm Bank, Department of Botany, University of North Bengal. The saplings were maintained in glasshouse under controlled condition of 30 $\pm 5^{\circ} \mathrm{C}$, relative humidity $60-80 \%, 16 \mathrm{~h}$ photoperid.

Fungal material: Glomerella cingulata (Stoneman) Spauld and Schrenk (anamoph of Colletotrichum gloeosporioides species complex [4]) was isolated from naturally infected susceptible tea plants (TV-22) in Phytopathological Experimental Garden and subsequently was identified (W7659) from the Diagnostic and Advisory Service, CABI Bioscience UK Center, and routinely subcultured on Richard's medium agar.

Treatment with inducer: Treatment with Benzothiadiazole [benzo(1,2,3) thiadiazole 7-carbothioic acid S-methyl ester, Hi Media] was done by spraying @ 100ml per plant with atomizer at $5 \mathrm{mM}$ aqueous solution concentration .

Plant inoculation: Whole plant inoculation technique as described by Mathur et al (2000) [5] was followed. Inoculation was done $48 \mathrm{~h}$ after treatment with BTH.
Spore germination visualization: In order to visualize infection process on the leaf surface, samples of leaves, at appropriate time interval, were cleared for a minimum of $24 \mathrm{~h}$ in a $1: 1$ solution of glacial acetic acid and $95 \%$ ethanol [6]. The leaf samples were then stained with $0.25 \%$ aniline blue in lactophenol. Leaf tissue was then examined with Olympus (CH20i) microscope under 100x magnification. Photographs were taken by a digital camera (Cannon).

Chitinase antibody:Polyclonal antibodies (PAbs) were raised against chitinase (Sigma) in New Zealand white male rabbits as per standard protocol [7].

\section{SDS-PAGE (Sodium Dodecyl}

Polyacrylamide Gel Electrophoresis) of soluble proteins: Total soluble proteins were extracted according to the method of Chakraborty et al (1995) [8] from untreated healthy, untreated inoculated, treated healthy and treated inoculated tea plants. Protein was run on SDS-PAGE by a standard procedure [9].

Western Blot: Western Blotting was done immediately after SDS-PAGE as described by Wakeham and White (1996) [10].

\section{RESULTS AND DISSCUSSION}

The results of $G$. cingulata spore germination and appressoria formation and germ tube length on induced and uninduced tea leaves 
have been presented in Table 1. It is clear from these results that in the induced resistant tea plants, there was suppression of spore germination percentage, appressoria formation and germ tube length. Appressoria are known to be very important structures in determining the host reaction towards the pathogen especially in case of Colletotrichum spp [11]. It is well known that percentage of spore germination and germ tube length growth rate are important factors in fungal pathogenesis.

Benzothiadiazole-treated tea plants showed formation of chlamydospores from conidia (Figure 1 E), sites of HR (Hypersensitive Response)-like response (Figure 1 F) and sites of attempted penetration (Figure $1 \mathbf{H}$ ) on the surface of leaves. Chlamydospores are thick walled resting structures produced in many fungi during unfavourable conditions $[12,13]$. These structures are known to be formed under unfavourable conditions and can be derived from fungal hyphae or directly from conidium [14]. Sites of attempted penetration are more characteristic of non-adapted (or non-host) plant pathogens [15], which in this case is incompatible reaction due to induction of resistance. 48 hours after inoculation there was heavy colonization of tea leaf tissues of untreated plants (Figure 1 D).

SDS-PAGE of Untreated Inocualted plants and Treated Inoculated plants exhibited one extra band of a low molecular weight protein with ca $12 \mathrm{kDa}$ that was absent in the untreated healthy and untreated inoculated plants. This protein may have some function in the protection of plants against pathogen. It is well-known that many low molecular weight pathogenesis-related proteins accumulate especially in the incompatible reactions [16]. The separated proteins were next blotted on to Nitrocellulose membrane and probed with $\mathrm{PAb}$ of chitinase. A distinct with molecular weight ca $29 \mathrm{kDa}$, especially in the treated inoculated plants (Figure 1 C), is visible on the blot. Thus chitinase showed involvement in defense reaction of tea plants associated with induced resistance, which supports the findings by Gupta et al (2012) [17], who reported chitinase of $32 \mathrm{kDa}$ induced to a greater extend in case of resistant cultivar than the susceptible one.

Table 1: Effect of induced resistance on spore germination, percentage appressoria formation and germ tube length of $G$. cingulata on tea leaf surface (TV-22)

\begin{tabular}{|c|c|c|c|}
\hline Treatment & \% spore germination & \% appressoria formation $^{\mathrm{a}}$ & Germ tube length $(\mu \mathrm{m})^{\mathrm{b}}$ \\
\hline Untreated Inoculated & $\mathbf{7 3 . 1} \pm \mathbf{3 . 2}$ & $\mathbf{6 6 . 8} \pm \mathbf{2 . 2}$ & $\mathbf{6 1 . 2} \pm \mathbf{2 . 8}$ \\
\hline BTH-treated Inoculated & $\mathbf{5 7 . 4} \pm \mathbf{2 . 7}$ & $\mathbf{2 2 . 7} \pm \mathbf{5 . 2}$ & $\mathbf{4 4 . 6 \pm 3 . 3}$ \\
\hline
\end{tabular}
germlings per experiment 

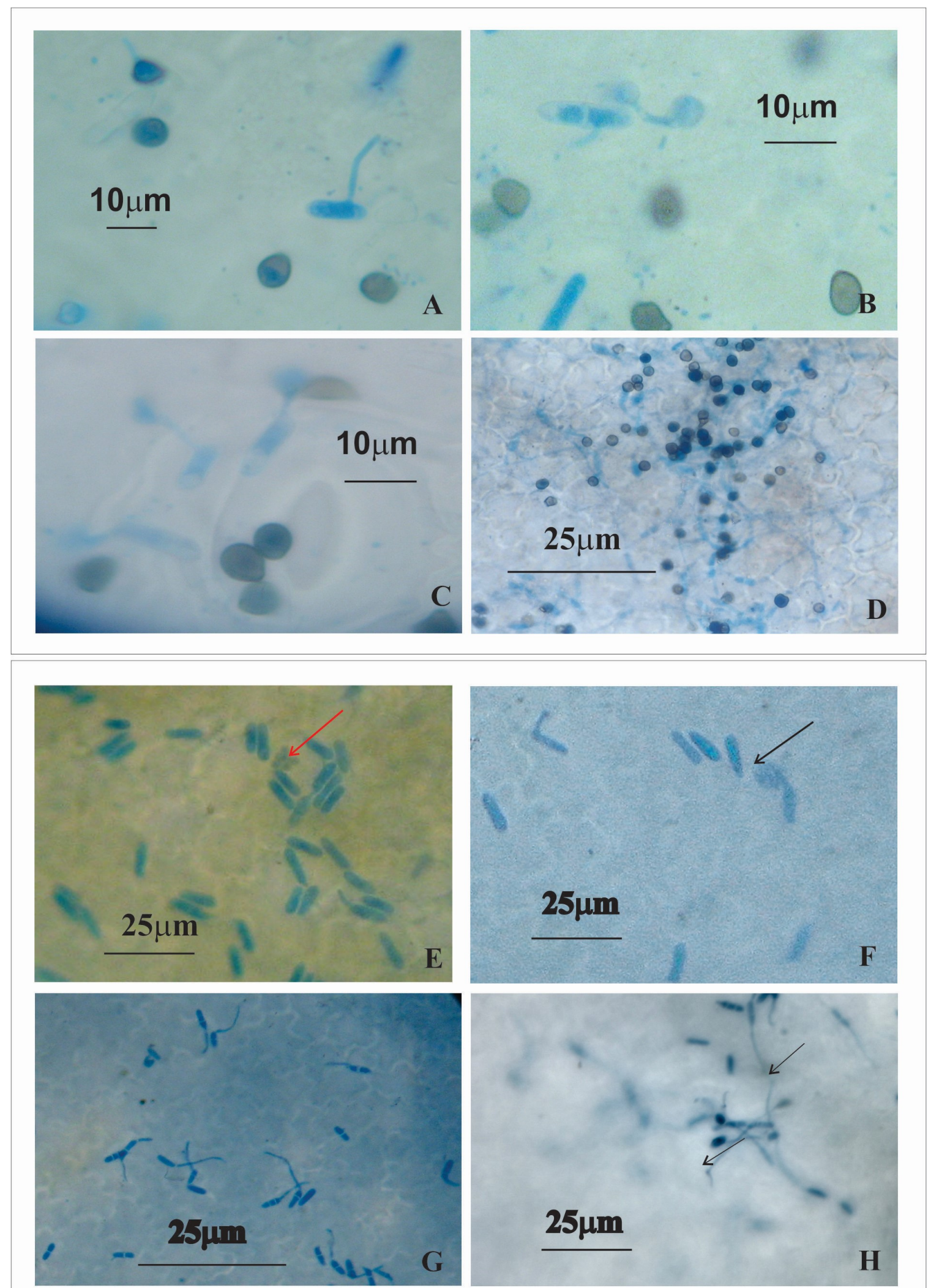

Figure 1: Progress of G.cingulata spore germination in untreated (A-D) and BTH-treated (E-H) tea plants (TV-22) leaves at $6 \mathrm{~h}(\mathrm{~A} \& \mathrm{~B}), 18 \mathrm{~h}(\mathrm{~B} \& \mathrm{~F}), 24 \mathrm{~h}(\mathrm{C} \& \mathrm{G})$ and $48 \mathrm{~h}(\mathrm{D} \& \mathrm{H})$ post inoculation 


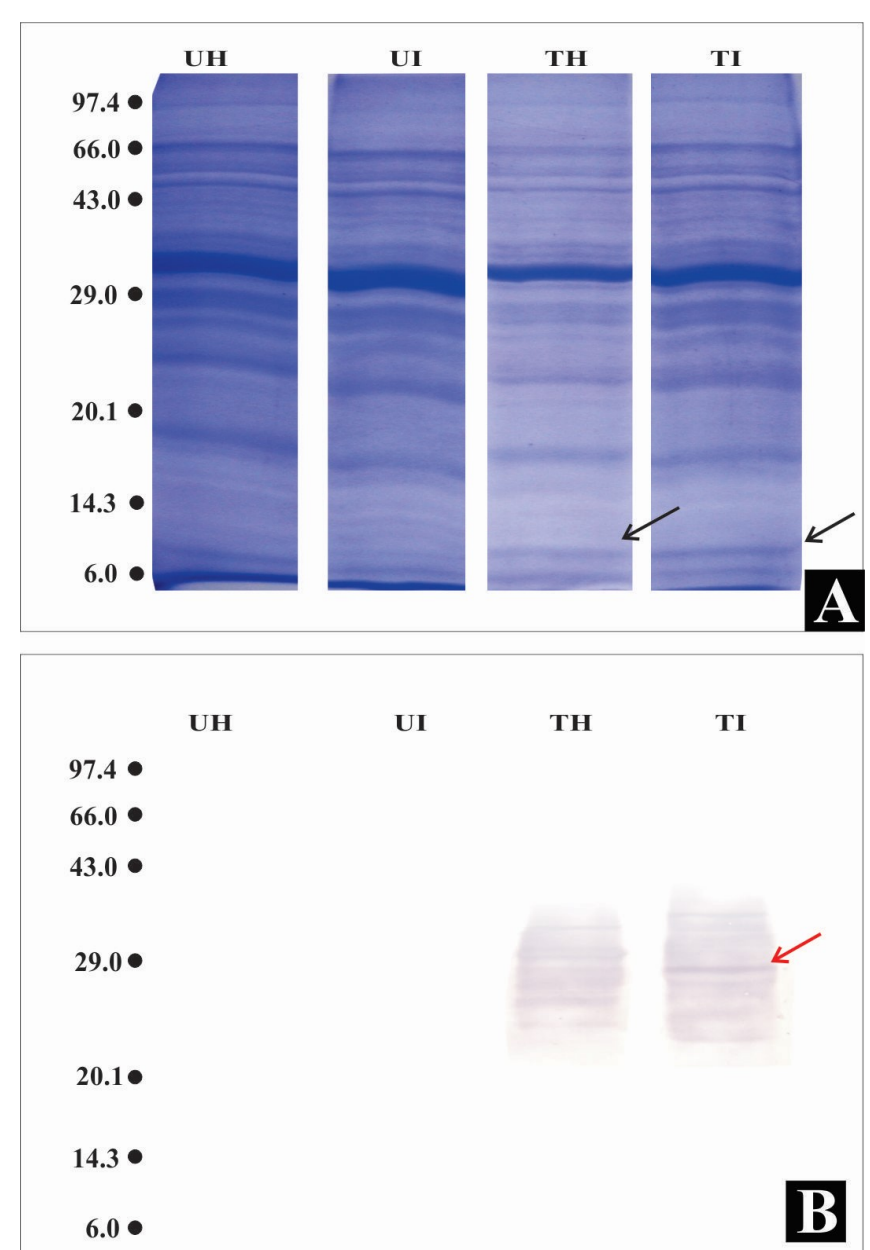

Figure 2: SDS-PAGE (A) and Western Blot with PAb of chitinase (B) in untreated healthy (UH), untreated inoculated (UI), treated healthy (TH) and treated inoculated (TI) tea leaf tissues. Black arrow indicates protein band of ca $12 \mathrm{kDa}$. Red arrow indicates a band of ca $32 \mathrm{kDa}$

NOTE: Figures on the left indicate Molecular Marker Weight in kDa

\section{CONCLUSION}

The present findings elucidate the mechanism of action of resistance induced with benzothiadiazole in tea plants against Glomerella cingulata. In planta observations, detection of an extra protein band ca 12 $\mathrm{kDa}$ ) via SDS-PAGE and chitinase (ca 32 $\mathrm{kDa}$ ) detection via Western Blot indicate the involvement of SAR (Systemic Acquired Resistance).

\section{ACKNOWLEDGEMENT}

The author is thankful to Botany Department, University of North Bengal for providing the infrastructure for conducting the work.

\section{REFERENCES}

[1] Hajra, G.N .Tea Cultivation. Comprehensive Treatise.

International Book Distributing

Company, Lucknow., 2001

[2] Chakraborty, U., Das, G. and Chakraborty, B.N. Factors 
influencing spore germination, appressoria formation and disease development in Camellia sinensis by Glomerella cingulata Folia.Microbiol, 40, 1995, 159-164.

https://doi.org/10.1007/BF02815415

[3] Som Paul R. Benzothiadiazole mediated induced resistance against brown blight of tea. Int $J$ Res Analytical Rev. 6 ( 2 ), 2019 , 377385

[4] Weir BS, Johnston PR, Damm U. The Colletotrichum gloeosporioides species complex. Studies in Mycology. 73, 2012, 115-180.

[5] Mathur, K., Thakur, R., P. and Rao, V. P. Pathogenic variability and vegetative compatibility among isolates of Colletotrichum graminicola and Colletotrichum gloeosporioides causing foliar and grain anthracnose in sorghum. Indian Phytopath. 53 (4), 2000, 407-414.

[6] Muchovej, J. J., and Couch, H. B. Colonization of bentgrass turf by Curvularia lunata after leaf clipping and heat stress. Plant Disease. 71, 1987, 873- 875.

[7] Chakraborty, B N and Purakayastha R P. Serological relationship between Macrophomina phaseolina and soybean cultivars. Physiol Plant Pathol, 23, 1983, 197-205.

[8] Chakraborty B N, Basu P, Das R, Saha A and Chakraborty U. Detection of cross-reactive antigens between Pestalotiopsis theae and tea leaves and their cellular localization. Ann Appl Biol, 127, 1995, 11-21.

[9] Sambrook J, Fritch E F and Maniatis T. Molecular cloning - a Laboratory Manual, $2^{\text {nd }}$ Edition, Book-3, 1989, pp 1860-1874

[10] Wakeham, A. J. and White, J. G. Serological detection in soil of Plasmodiophora brassicae resting spores. Physiol. Mol. Plant Pathol. 48, 1996, 289- 303.

[11] Yong, H.Y., Bakar, F.D.A., Illias, R.M., Mahadi, N.M., \& Murad, A.M.A. Cgl-SLT2 is required for appressorium formation, sporulation and pathogenicity in Colletotrichum gloeosporioide. Brazilian Journal of Microbiology, 44(4), 2013, 12411250. https://doi.org/10.1590/S1517 $-83822013000400031$

[12] Kang, Y, Kim, M, Kim, K, Lee J and Lee, S.-H. Chlamydospore Induction from Conidia of Cylindrocarpon destructans Isolated 
from Ginseng in Korea.

Mycobiology. 44(1), 2016, 63-65.

[13] de Silva, D.D., Groenewald, J. Z., Crous, P.W, Ades, P.K, Nasruddin. A., Mongkolporn, O. and Taylor, W.J. Identification, prevalence and pathogenicity of Colletotrichum species causing anthracnose of Capsicum annuum in Asia. IMA Fungus 10: 8, 2019.

https://doi.org/10.1186/s43008-0190001-y

[14] Sun ZB, Zhang J, Sun MH, Li SD. Identification of genes related to chlamydospore formation in Clonostachys rosea 671. Microbiologyopen.; 8(1): 2019, doi:10.1002/mbo3.624

[15] Yang L, Qin L, Liu G, Peremyslov VV, Dolja VV, Wei Y. Myosins XI modulate host cellular responses and penetration resistance to fungal pathogens. Proc Natl Acad Sci U S A., 111(38), 2014; 13996-14001. doi:10.1073/pnas.1405292111

[16] Elvira, M. I., Galdeano, M. M., Gilardi, P., Garc1'a-Luque, I. and Serra, M.T. Proteomic analysis of pathogenesis-related proteins (PRs) induced by compatible and incompatible interactions of pepper mild mottle virus (PMMoV) in Capsicum chinense $\mathrm{L}^{3}$ plants. Journal of Experimental Botany, 59(6), 2008, 1253-1265.

doi:10.1093/jxb/ern032.

[17] Gupta P, Ravi I and Sharma V. Induction of $\beta$-1,3-glucanase and chitinase activity in the defense response of Eruca sativa plants against the fungal pathogen Alternaria brassicicola J Plant Interac, 8(2), 2013, 155-161.

https://doi.org/10.1080/17429145.20 $\underline{12.679705}$ 